Jurnal Administrasi Publik (Public Administration Journal)

\title{
Bureaucracy Reform In Purworejo District Attorney
}

\author{
Endah Titi Wigati1)*, Samodra Wibawa ${ }^{2)}$ \& Faizal Madya ${ }^{1)}$ \\ 1) Public Administration Study Program, Faculty of Law, Social and Political Sciences, \\ Universitas Terbuka, Indonesia \\ 2) State Administration Study Program, Faculty of Social and Political Sciences, \\ Universitas Gadjah Mada, Indonesia
}

Received: 29 December 2020; Reviewed: 21 February 2021; Accepted: 23 April 2021

* Email Coresponding:endahwigati@gmail.com

\begin{abstract}
Bureaucratic reform is needed to make the government more efficient and effective. Purworejo District Attorney has implemented this bureaucratic reform since 2008. This study aims to describe the process of implementing Bureaucratic Reform at the Purworejo District Attorney in five aspects, institutional and organizational effectiveness, management, human resources, accountability and service. The method used is descriptive research with a qualitative approach. Interview data through interviews. The implementation of Bureaucratic Reform at the Purworejo District Prosecutor's Office was carried out in several stages, namely Phase I (2008-2009), Phase II (2010-2014), Phase III (2015-2019) and current conditions. Bureaucratic Reform at the Purworejo District Attorney has implemented the Integrity Zone to restore public trust, empower functional prosecutors to improve law enforcement, provide contact for public complaints, implement one stop sevices, use Information Technology to support their duties and functions. However, there are still some weaknesses, namely organizational organizations, organizations consisting of a combination of control functions and functions, responsible organization, and unsuitable employee placement.
\end{abstract}

Keywords: Bureaucratic Reform; District Attorney; Integrity Zone; Purworejo.

How to Cite: Wigati, E.T., Wibawa, S., \& Madya, F. (2021). Bureaucratic Reform at the Purworejo District Prosecutor's Office. Jurnal Administrasi Publik : Public Administration Journal. 11 (1): 77-87. 


\section{INTRODUCTION}

Bureaucratic Reform is a strategic step to carry out the development of the government apparatus so that it is more efficient and effective in carrying out general tasks of government and national development. In addition, the rapid progress of science, information and communication technology and changes in the strategic environment requires that the government bureaucracy be changed and adapted to the demands of society. Thus, steps must be taken which are basic, comprehensive and systemic in nature, so that the stated goals and objectives can be achieved effectively and efficiently.

The good name of the AGO was tarnished due to the actions of internal elements of the Attorney who did not commendable deeds in the implementation of handling cases which had an impact on the image of the institution as a whole. It is the right time for the AGO to carry out reforms in order to restore the image of the AGO to the public.

One of the bureaucratic institutions that carried out bureaucratic reform is the State Attorney, especially the Purworejo District Attorney. The Purworejo District Attorney was taken as an object because the Purworejo District Attorney was one of the examples of bureaucratic reform that was implemented in 2007. In addition, the Attorney is an institution that has carried out an Independent Assessment of the Implementation of Bureaucratic Reform in 2013, reaching $70.33 \%$. In addition, the Attorney General's Office also obtained a WTP (Unqualified) opinion for financial reports that have been audited by the BPK (Supreme Audit Agency) from 2013 to 2019. Another interesting thing to discuss about the reform of the attorney's bureaucracy is that the Attorney General's Office won 8th place for the management of the website version of the State Secretariat in 2012 and there is also an increase in the remuneration of Attorney Offices and also allowances for Prosecutors. Several things above underlie the importance of conducting research at Purworejo District Attorney because there is no data on the results of the implementation of Bureaucratic Reform at Purworejo District Attorney.

$$
\text { Based on Dwiyanto (2014), }
$$
bureaucratic reform is a significant change in the elements of the bureaucracy, including: institutions, human resources as apparatus, management, apparatus accountability, supervision and public services. Some examples of bureaucratic reform include institutional reform and financial personnel, treasury, planning and budgeting, immigration, land and investment. The most important thing about bureaucratic reform itself is changing the mind set and culture set as well as the development of work culture.

Service functions provided by the government, according to Leach, et.al. (in Pinem, 2011), have four alternative models of authority used in providing services, namely traditional bureaucratic authority, residual enabling authority, market oriented authority, and community oriented enabler. Services provided by the government by adhering to the traditional bureaucratic authority are services provided directly by local governments.

Several studies on Bureaucratic Reform have been carried out, among them are by Nuh (2013) with a study entitled "The Effect of Bureaucratic Reform on Public Sector Labor Productivity: Case Studies at Five State Treasury Service Offices in East Java" results that education to employee work productivity in public sector organizations when continuing education is more motivated by promotion and position, not State Treasury Service Office to increase productivity. The age difference factor of employees did not 
affect the work productivity of State Treasury Service Office employees; Ardiansyah (2015) in the study entitled "Bureaucratic Reform in the Organization and Administration Sector at the Ministry of Marine Affairs and Fisheries", it was found that the Ministry of Marine Affairs and Fisheries had not yet reached the target of the proposed areas of change until early 2014. Especially in the area of organizational change and management in 2014 , it scored 2.82 out of a maximum of 6.00 for the organizational structuring and strengthening program and a score of 3.63 from a maximum of 5.00 for the management structuring program. The results of the research indicated that the bureaucratic reform in the field of organization and management in the Ministry of Marine Affairs and Fisheries faced several problems, among them are the main tasks and functions overlap both internally and externally in the organization and there are differences in interests between implementation actors and insufficient budget resources during program implementation; Yusuf (2018) in the study entitled "Bureaucratic Reform in Public Service at the Office of Agrarian and Spatial Planning/ the National Land Agency (ATR/ BPN) in Maros Regency" obtained results that the implementation of bureaucratic reform in public services at the Spatial Agrarian Office / National Land Agency (ATR / BPN) Maros Regency has not been able to achieve the creation of public services in the Land Sector according to the procedures as stipulated by the Head of the National Land Agency of the Republic of Indonesia regarding Land Service Standards and Regulations in the management of land certificates. It is due to the large number of priority programs that are given directly from the center coupled with the routine services faced which makes the workload excessive so that the availability of human resources, in this case the surveyor staff, is only 7 people, while the land to be measured has a large enough plot, approximately 9,354 fields each years and in implementing reforms in the regions that cannot be carried out, namely recruitment of employees; Adnan (2013) with a study entitled "Reform of the Regional Government Bureaucracy in Efforts to Improve Public Services", was found that there were several problems faced by the local government bureaucracy so that the bureaucracy had not been able to improve public services optimally; Hermawan (2011) with a study entitled "Evaluation of Bureaucratic Reform in the service sector in Kudus Regency" results that excellent service in realizing bureaucratic reforms in vehicle eligibility certification services had not been well manifested; Lituhayu (2015) with a study entitled "Bureaucratic Reform in the Field of Organization in Pekalongan Regency" results that observed phenomena include overlapping, right screening, organizational efficiency and effectiveness, organizational capacity of regional apparatus and employee development; Juwandi (2015) with the study's title "The Effectiveness of Bureaucratic Reform in the Context of Civic Skills as an Effort to Realize" results that based on the research results, It was found that the services provided by West Java Province BPMPT (Investment Board and Integrated Service) had shown improvements in the quality of licensing services in accordance with service principles; Tome (2012) with a study entitled "Bureaucratic Reform in the Framework of Realizing Good Governance in terms of the Regulation of the Minister for Empowerment of State Apparatus and Bureaucratic Reform Number 20/2010", was found that the implementation of bureaucratic reform in North Sulawesi has generally not achieved very satisfactory results.

Based on several previous studies that have been carried out, the objective of 
this study is to determine the application of Bureaucratic Reform and to analyze the strengths and weaknesses of the implementation of bureaucratic reform at Purworejo State Attorney.

\section{RESEARCH METHOD}

This type of study was descriptive qualitative. In qualitative research, the most important thing is how to determine key informants who are full of information in accordance with the focus of the research as stated by Tanjung (2007). Qualitative methods can be used to express and understand something behind a phenomenon that is not even the least bit known. This method can also be used to gain insight into something that is little known, and can help the researchers provide complex details about phenomena that are difficult to be expressed by quantitative methods based on Strauss \& Corbin (2013).

For knowing Reform of the Bureaucracy at Purworejo District Attorney, the use of qualitative method was used to conduct descriptions and analysis of the implementation of the Purworejo District Attorney's Office of Bureaucratic Reform; Implementation of bureaucratic reform at Purworejo District Attorney in the areas of institutions, management, human resources, accountability and services.

The consideration in determining the base informants and main informants were officials at Purworejo District Attorney who had extensive knowledge and understanding of the conditions of the Purworejo District Attorney, especially in the field of implementing Bureaucratic Reform.

Data were collected through interviews with resource persons consisting of six people consisting of structural officials and employees at the Purworejo District Attorney and two users of Purworejo Public Attorney. The interview data were analyzed and outlined in the results and discussion.

\section{RESULTS AND DISCUSSION Implementation of Phase I Bureaucratic Reform (2008-2009 Period)}

Strategic Direction, Acceleration Program (Quick Wins), to determine the program was implemented, the Purworejo District Attorney identified the most critical areas including the areas of institution, management and human resources as well as aspects of the main duties and authority of Purworejo District Attorney. The performance of Purworejo District Attorney has shown a significant upward trend from year to year. From the performance report of Purworejo District Attorney in 2008, it can be seen that during 2008 Purworejo District Attorney succeeded in completing 16 cases out of 47 SPDP (Notification of Commencement of Investigations).

With regard to the program for accelerating the handling of General Crime and Corruption cases, activities carried out include reviewing regulations related to case handling, policy making related to management organizational structures and institutional support as well as monitoring and evaluation by the Head of the Purworejo State Attorney to accelerate or optimize handling of General Non-Criminal Cases and Corruption Crimes by the Purworejo District Attorney.

Information system (on line) handling case the criminal act of corruption utilized the existing SIMKARI facilities, by optimizing its function in the data aspect. In addition to the data aspect, the optimization carried out by the Quick Wins team also includes aspects of infrastructure, the application of the Special Crime Management Information System (SIMPIDSUS), and Human Resources. 
System Arrangement, was by carrying out Job Analysis, Job Evaluation and Remuneration System to motivate performance, integrity, professionalism and productivity of Purworejo District Attorney. Therefore, the amount of remuneration received was very dependent on the performance of each individual. As a prerequisite for being eligible for remuneration, Purworejo Public Attorney's employees signed the Integrity Pact with the consequence that if they violate the Integrity Pact, an employee of the Purworejo Public Attorney can lose their employment status. So it can be concluded that remuneration is fluctuating depending on the performance of each employee.

Renewal Program, to carry out the Renewal Program, Purworejo District Attorney formed a Prosecutor's Reform Team, consisting of Prosecutor's Structural Officials, Prosecutors' Experts and Permanent Staff at the Attorney. The Head of the Purworejo District Attorney acts as the Coordinator of the Prosecutor's Reform Team. The results of the implementation of Purworejo District Attorney's Office Renewal Program of the draft reform policy as outlined in the six regulations that contained provisions on improving the Attorney's HR Management which contain elements of reform, such as guaranteeing an objective, transparent and accountable system to increase professionalism, performance and integrity of prosecutors and other public prosecutors. The six Regulations include: a) Prosecutor Candidate Recruitment System Regulations; b) Career Development Regulations; c) Education and Training Regulations; d) Code of Conduct of the Prosecutor e) Minimum Standards for the Prosecutor's Profession; f) Regulations for Supervision Operations.

Management Changes, reforms of the Purworejo District Attorney were basically a series of systematic and planned efforts to make reforms and changes fundamentally to the governance system, especially regarding institutional, management and Human Resources aspects.

\section{Implementation of Phase II Bureaucratic Reform (Period 2010- 2014)}

Institutional and Organizational Effectiveness: Redefinition of vision, mission and strategy. Bureaucratic reform iwas directed at creating a clean, responsible, professional, effective and efficient bureaucracy and creating excellent service to the community starting from the implementation of redefinition of vision, mission and strategy, review of restructuring of separation and merger and sharpening of functions, study of workload analysis of units organizational unit to optimize the duties and functions of Purworejo District Attorney.

Restructuring, the changes in the internal organizational structure of the Purworejo District Attorney aimed to support the implementation of Bureaucratic Reform.

Workload Analysis, Purworejo District Attorney compiled a Workload Analysis Assistance Team in accordance with Kepja Number: KEP-053 / A / JA / 05/2009.

Management, which aims to increase the efficiency and effectiveness of clear, effective, efficient and measurable work systems, processes and procedures at the Purworejo District Attorney, was carried out by: a) The formulation of management produces SOPs as a standard for employees in completing the work which is their responsibility to reduce errors, negligence and violations of employees in carrying out their duties. b) E-office and Records Management: Paperless Concept, aims to reduce the use of paper with digital letter disposition; CMS SPPT-IT, Information Technology-based Integrated Criminal Case Management System 
(SPPT-IT) is a form of collaboration between Law Enforcement Agencies, namely the Attorney, Police, Courts and Prisons.

Human Resources, aimed at improving the professionalism of human resources in order to achieve the stated goals. As for the steps that have been taken, namely: 1) Individual Competency Assessment for Prosecutors and Employees / Document / Archive Expert, Individual assessment was carried out on 4 prosecutors to see the readiness and suitability of competence to move up to a higher level in accordance with the mandate of the Presidential Regulation Number 100 of 2000 concerning Appointment of Civil Servants in structural positions. 2) Building a performance appraisal system, performance appraisal is formulated based on the results of the implementation of job analysis and workload analysis to formulate strategies and policies in the field of human resources. Purworejo District Attorney conducted a performance appraisal using the "Blue Book" which contained the track record of the activities of each prosecutor, use of a credit score scoring system for functional officials and a scoring system through DP3 for all civil servants. 3) Developing a Procurement and Selection System.

The Attorney conducted a review of the recruitment process and system currently underway. 1) Accountability, the aspect of accountability is realized by Strengthening Supervision which aims to improve governance that is clean and free from KKN within the scope of the Purworejo District Attorney. The steps taken are enforcing work discipline by establishing activities to make effective monitoring and handling of complaints by referring to Perja Number PER-022 / A / JA / 03/2011 concerning the Implementation of Supervision by the Republic of Indonesia Attorney General's
Office. In addition, by enforcing the code of ethics at the Purworejo District Attorney and socializing the rules so that judicial regulations understand the rules that must be carried out in carrying out the main tasks of the judiciary.

Service, the basis for the implementation of public quality improvement at the Purworejo District Attorney, namely the issuance of a Regulation on Public Information Service Standards at the Attorney Number PER032 / A / JA / 08/2010 concerning Public Information Services for the Attorney General's Office. In order to carry out public services optimally at the Purworejo District Attorney, an Information and Documentation Management Officer (PPID) was formed which was held by the Head of the Intelligence Section.

\section{Implementation of Phase III Bureaucratic Reform (2015-2019 Period)}

Institutional and Organizational Effectiveness. In this stage, a 2014 Performance Evaluation was carried out with the aim of knowing the objective conditions of Purworejo District Attorney's performance in implementing various principles and also measuring the achievement of organizational work results as well as laws and regulations related to the Purworejo District Attorney. The compilation of Purworejo District Prosecutors' Profile in 2025 was also carried out through in-depth study processes and stages.

Management, in this phase, was done by mapping the work process (business process) within Purworejo District Attorney which was followed up by mapping the Main Performance Indicators (IKU) as the basis for the preparation of the Unit Performance Assessment Instrument (IPKU). In addition, standardization and review of SOPs in all fields within Purworejo District Attorney were in line with the results of the work 
process mapping as well as in accordance with the new guidelines for drafting SOPs issued by the Ministry of PAN-RB in 2012.

Human Resources, in this phase a competency assessment was carried out which is part of the efforts to improve the quality and improvement of the HR development system at Purworejo District Attorney in collaboration with a third party Assessment Center. The objective of this collaboration was to determine the quality of human resources at Purworejo District Attorney. In addition, CPNS (Candidates for Civil Servants) recruitment was also carried out for the formation of Purworejo District Attorney by utilizing Information Technology and carried out in a transparent and accountable manner through http: L/formasi,kejaksaan.go.id/rekrutmen/.

Accountability, at this stage Purworejo District Attorney had succeeded in obtaining an Unqualified BPK opinion (WTP) on the presentation of the Purworejo Public Prosecutors' financial statements for 2014 to 2019, developing a management system for the evaluation results of the Prosecutor Performance Assessment Instrument (IPKJ), and developing a performance appraisal instrument. units and individuals.

The service, at this stage, has held a public relations unit training for the Head of the Intelligence Section and his staff at Purworejo State Attorney and formed a Saber Pungli Unit at the Purworejo District Attorney based on Presidential Regulation Number 87 of 2016 dated 20 October 2016.

\section{Implementation of Bureaucratic Reform in Current Conditions}

As a realization of the implementation of Bureaucratic Reform, the Purworejo District Attorney for 2020 will focus on the Development of an Integrity Zone towards WBK (Corruption-
Free Areas) and WBBM (Clean Bureaucratic Serving Areas).

Institutional and Organizational Effectiveness was carried out by mapping regulations, deregulation and formulating new internal regulations at the Purworejo Public Attorney, restructuring the Purworejo Public Prosecutors' Organization gradually in the long term and analyzing workloads based on plans to develop future organizational structures.

Management: 1) Develop and implement operational procedures referring to the duties and functions of the Purworejo Public Attorney, namely making SOP units which were derived from the SOPs issued by Republic of Indonesia's Attorney and making SOP innovations by adjusting the regional conditions of Purworejo District Attorney. 2) Perform unit performance measurement system by implementing eoffice (IT-based office system); 3) The HR management system used the latest staffing Simkari application; 4) Implementing public information disclosure in the form of requirements, flow, time and costs through banners / banners, websites and social media.

Human Resources: 1) Planning the needs of employees according to the needs of the organization and making a letter of proposal for the needs of employees to the Central Java High Attorney along with the required position formations by referring to Kepja No. KEP614 / A / JA / 10/2017 concerning Classification of Structural and Functional Positions within the Republic of Indonesia's Attorney General's Office; 2) Implementing the internal mutation pattern according to the Local mandate which is the implementation of Kepja Number 356 of 2019 concerning local mutations; 3) Carry out the competencybased employee development by conducting Training Need Analysis for competency development by holding 
meetings for the preparation of training / technical guidance / employee development needs analysis;

Accountability: 1) The involvement of the top leaders in preparing the Strategic Planning Document of Purworejo Public Attorney which presents the desired development direction by taking into account the internal conditions of the Attorney including its resources, achievement strategies and success measures; 2) Performance Accountability Management which consisted of managing performance data, measuring performance and reporting performance. The implementation of the main and additional performance indicators has been carried out with the principles of Specific, Measurable, Achievable, Relevant and Timely (SMART) and carried out by competent human resources.

Services: 1) Implementing a culture of excellent service by providing information that was easily accessible to the user community, including providing directions for places (PTSP, Field, Ticketing Counter / Evidence, Receptionist, Mosque, Toilet, Meeting Room, etc.) a mobile friendly website so that the public can access information on case handling developments and publication of the Integrity Zone development; 2) Providing integrated services at Purworejo District Attorney, namely One Stop Integrated Service, which was an integrated service among all fields so that make it easier for the public to access information and services available at the Purworejo District Attorney, which consists of: a) Case Services and Case Administration; b) Legal Services and Legal Consultation; c) Legal and Case Information Services; d) Public Complaint Services; e) Evidence / Confiscated and Detained Goods Services; f) Ticketing Service; g) Correspondence Administration Services.

\section{Weakness and Strength}

The weaknesses of the implementation of the Bureaucratic Reform at $\mathrm{t}$ Purworejo District Attorney are: 1) Flexibility, namely Purworejo District Attorney did not have the authority to resolve organizational structure problems because the format of the Attorney's organizational structure must refer to the general format of the Attorney General's Office which created the difficulties for the Attorney because it has special characteristics which were influenced by different duties and authorities from other government agencies, giving rise to difficulties for the Attorney to adapt to the dynamics of change and future challenges; 2) The combination of the policy-making function was mixed with the case control function and the administrative control function so that the main function of Purworejo District Attorney in conducting prosecutions was less focused. Thus, it is necessary to separate the case control function and the administrative control function; 3) Lack of synchronization between sections, which was seen from the planning of organizational performance that was not yet fully aligned among sections because it was still focused on the main task of each section and had not paid attention to overall relationships and harmony with other parts; 4) In the performance analysis, there was still an overlap among the divisions, causing the difficulties in assessing performance and making strategies and policies in the field of human resources; 5) The Personnel Sector focused on personnel administrative functions, has not carried out a detailed analysis of employee turnover forecasts, analyzed the competence of existing employees and analyzed the needs of employees according to job qualifications;

The advantages of implementing the Reform at Purworejo District Attorney, 
namely: 1) Application of the Integrity Zone towards the Corruption Free Area (WBK) and the Clean Serving Bureaucratic Area (WBBM); 2) Has empowered functional prosecutors to improve the implementation of Purworejo District Attorney's duties in enforcing justice, ensuring the provision of career positions/ positions of prosecutors, the main duties of prosecutors run optimally in handling cases appropriately and quickly in accordance with the direction and objectives of the law; 3) Availability of contact numbers for public complaints that were installed in strategic places to receive reports of public complaints to be followed up as a form of service to the public; 4) Application of e-office to support the performance of Purworejo District Attorney which has been implemented in the field of employment, archives, correspondence and leadership disposition aimed at efficiency and effectiveness of manpower and time as well as encouraging the role of the community as a control medium in assessing the performance of the Purworejo District Attorney to prevent fraud; 5) Availability of PTSP (One Stop Integrated Service) which made it easy for the public to obtain information about ticketing, receipt of letters or case handling files that had been transferred from the Purworejo Police to the Purworejo District Prosecutors' Office; 6) The role of the leadership was more, namely by being directly involved in several activities such as the preparation of performance planning and performance determination so as to increase employee morale to carry out activities.

The advantages of implementing the Reform at Purworejo District Prosecutor's Office, namely: 1) Application of the Integrity Zone towards the Corruption Free Area (WBK) and the Clean Serving Bureaucratic Area (WBBM); 2) Has empowered functional prosecutors to improve the implementation of the Purworejo District Attorney's duties in enforcing justice, ensuring the provision of career positions / positions of prosecutors, the main duties of prosecutors run optimally in handling cases appropriately and quickly in accordance with legal directions and objectives; 3) Availability of contact numbers for public complaints that are installed in strategic places to receive reports of public complaints to be followed up as a form of service to the public; 4) The application of e-office to support the performance of Purworejo Public Prosecutor's Office which has been applied in the field of personnel, archives, correspondence and leadership dispositions aimed at efficiency and effectiveness of personnel and time as well as encouraging the role of the community as a control medium in assessing the performance of Purworejo District Attorney to prevent fraud. ; 5) Availability of PTSP (One Stop Integrated Service) which made it easy for the public to obtain information about ticketing, receipt of letters or case handling files that have been transferred from the Purworejo Police to the Purworejo District Prosecutors' Office; 6) The role of the leadership was more, namely by being directly involved in several activities such as the preparation of performance planning and performance determination so that increase employee morale to carry out the activities.

\section{CONCLUSION}

The implementation of Bureaucratic Reform at Purworejo District Attorney had done through several stages, namely Phase I Bureaucratic Reform in the 20072009 period, Phase II Bureaucratic Reform in the 2010-2014 period, Phase III Bureaucratic Reform in the 2015-1029 period, and Bureaucratic Reformation which implemented at current time. The 
bureaucratic reform carried out by the Purworejo District Attorney which includes five aspects of bureaucratic reform had received a good response from all employees at the Purworejo District Attorney and had also improved the performance of employees at the Purworejo Public Attorney by influencing and changing the mindset, work culture and employee performance that was always maintain a professional attitude and uphold the values of morality, maintain personal integrity as a Prosecutor and Administration,

The advantages of implementing Bureaucratic Reform at Purworejo District Attorney are that Purworejo District Attorney had implemented the Integrity Zone towards the Corruption Free Area (WBK) and the Clean Serving Bureaucratic Area (WBBM) to improve morale and ethics of law enforcement, empower functional prosecutors to improve the implementation of the Purworejo State Prosecutors' duties, providing contact numbers for public complaints to be followed up, implementing e-offices to support the performance of the Purworejo District Attorney which has been implemented in the field of staffing, archives, correspondence and leadership dispositions aimed at efficiency and effectiveness of personnel and time, PTSP (One Stop Integrated Service) which make it easier for the public to obtain information about tickets,receipt of letters or case handling files and the role of the leadership was more prominent by being directly involved in the activities carried out.

Fom the several strengths described earlier, there were still some weaknesses, namely the Attorney General's Office id not have the authority to resolve organizational structure problems because the format of the Attorney's organizational structure must refer to the general format of the Attorney General's
Office. The combination of policy-making functions was mixed with case control functions and administrative control functions so that the main function of the Purworejo District Attorney in conducting prosecutions was not strong enough, the planning of organizational performance was not yet fully aligned between sections because it was still focused on the main tasks of each section and had not paid attention to overall relations and harmony with other departments, there was an overlap among divisions, causing the difficulties in performance appraisal and formulation of strategies and policies in the field of human resources as well as the placement of employees had not yet based on organizational needs and criteria.

\section{BIBLIOGRAPHY}

Adnan, M.F. (2013). Reformasi Birokrasi Pemetintahan Daerah Dalam Upaya Peningkatan Pelayanan Publik. Jurnal Ilmu Sosial. Padang: Universitas Negeri Padang.

Dwiyanto, A. (2012). Mewujudkan Good Governance Melalui Pelayanan Publik. Yogyakarta: Gajah Mada University Press.

Hermawan, E. (2011). Evaluasi Reformasi Birokrasi pada Sektor Pelayanan di Kabupaten Kudus (tesis). Semarang: Universitas Diponegoro.

Juwandi, R. (2015). Efektivitas Reformasi Birokrasi dalam Konteks Kecakapan Warga Negara (Civic Skill) Sebagai Upaya Mewujudkan Good Governance (Tesis). Bandung; Universitas Pendidikan Indonesia.

Lituhayu, D. (2015). Reformasi Birokrasi Bidang Organisasi di Kabupaten Pekalongan (Jurnal Ilmu Sosial). Semarang: Universitas Diponegoro.

Nuh, M. (2013). Pengaruh Reformasi Birokrasi Terhadap Produktivitas Tenaga Kerja Sektor Publik : Studi Kasus pada Lima Kantor Pelayanan Perbendaharaan Negara di Jawa Timur (Jurnal Ilmiah). Malang: Universitas Brawijaya.

Putra, S.A. (2015). Reformasi Birokrasi Bidang Organisasi dan Tata Laksana di Kementrian Kelautan dan Perikanan. Jurnal Ilmu Sosial dan Ilmu Politik. Malang: Universitas Brawijaya.

Pinem, R. (2011). Analisis Pengaruh Implementasi Kebijakan Desentralisasi terhadap 
Pembangunan Ekonomi Wilayah di Kabupaten Karo (tesis), Medan: Universitas Sumatra Utara.

Samin, R. (2011). Reformasi Birokrasi. Jurnal Fisip UMRAH, Vol. 2 (2): 172-182.

Sjahrir, B. S., Kis Katos, K., \& Schulze, G. G. (2013). Political budget cycles in Indonesia at the district level. Economic Letters, 120(2), 342-345.

Straus, A. \& Corbin, J. (2013). Dasar-dasar Penelitian Kualitatif, Yogyakarta: Pustaka Pelajar.

Tanjung. (2007). Manajemen Motivasi. Penerbit PT Grasindo. Jakarta

Tome, A.H. (2012). Reformasi Birokrasi dalam Rangka Mewujudkan Good Governance Ditinjau dari Peraturan Menteri Pemberdayaan Aparatur Negara dan
Reformasi Birokrasi Nomor 20 Tahun 2010 (Artikel). Gorontalo: Universitas Negeri Gorontalo.

Wibawa, S., Prasetyo, A.G. \& Nur'aini, D.A. (2020). The Roots of Administrative Reform in Indonesia. International Journal of Innovation, Creativity and Change, Vol. 13, Issue 11.

Wihantoro, Y., Lowe, A., Cooper, S., \& Manochin, M. (2015). Bureaucratic reform in post asian crisis indonesia: the directorate general of tax. Critical Perspectives on Accounting, 31, 44-63.

Yusuf, A.P. (2018). Reformasi Birokrasi Dalam Pelayanan Publik pada Kantor Agraria dan Tata Ruang/Badan Pertanahan Nasional (ATR/BPN) Kabupaten Maros (Tesis). Makasar: Universitas Hasanuddin. 